\title{
The prosodic structure in Basque
}

\author{
Mélanie Lancien ${ }^{1}$, Philippe Martin ${ }^{2}$, \\ ${ }^{1}$ Laboratoire de Phonétique et Phonologie, UMR 7018, CNRS/Sorbonne Nouvelle, \\ France \\ ${ }^{2}$ LLF, UMR 7110, CNRS / Université Paris Diderot-Paris 7, France \\ https://doi.org/10.36505/ExLing-2017/08/0016/000318
}

\begin{abstract}
Basque is a lexically stressed language where patterns in accented phrases have been reported to change from region to region (Olano, 2006). In order to better understand 1) the positioning of lexical stress in accent phrases and 2) the prosodic characteristics of stressed syllables in the indication of prosodic structures, we recorded 4 Basque native speakers form Alava, Gipuzkoa, and Labourd on a selection of sentences readings. Results showed that data on Gipuzkoa Basque were consistent with the contrast of melodic slope model (Martin, 1975). The lexical stress was found to be on the last syllable of the full lexical item, and not just on its stem. In a case study, we also evidenced a possible prosodic grammar of contours for Gipuzkoa Basque.
\end{abstract}

Key words: Basque, prosodic structure, melodic slope

\section{Introduction}

Basque has been described in detail since the 17th century but mostly in the syntactical and lexical domains. Phonetics studies of the different varieties of Basque started in the late 20's with Gavel (1921) and Larrasquet (1928). These studies were far away from nowadays' experimental phonetics and phonology, and mostly aimed at describing how phonemes were pronounced in different dialects. All studies made on Basque dialects reported a great variation, sometimes even between two very geographically close regions of the Basque country.

Most studies on prosody or accentuation in Basque languages did use the ToBI annotation system, pooling together phonetical and phonological prosodic cues and using a very restrictive set of indexes for pitch height and phrases boundaries. Already in 1729, Larramendi in his grammar of Gipuzkoa Basque, evidenced a prosodic system mainly instantiated by a stress located on the final syllable of the stem (e.g. no stress on the suffix). Hualde (2004) confirmed that this pitch accent was coherent with modern varieties of Gipuzkoa Basque.

To globally summarize the varieties of accentual patterns found in Basque dialects, Michelena (1972, 1977, 2013) described 4 categories of Basque: type 1 mostly spoken on the western side of the Basque country, have a tonal pattern consisting of several high pitch syllables followed by several low pitch syllables forming tonal plateau. Types 2, 3 and 4 have a primary accent

ExLing 2017: Proceedings of 8th Tutorial and Research Workshop on Experimental Linguistics, 19-22 June, Heraklion, Crete, Greece 
on one syllable per stem with no possible accent clash. These stress accent types are mostly found in the East side of the Basque Country.

\section{Methods}

To investigate Basque accentuation and prosody in several dialects, we designed sentences of increasing complexity (such as: Katua jaten du - The cat is eating - $\rightarrow$ Katu zuri beltza nere amonaren lorategian xaguak jaten ari da. - The small black and white cat is eating mice in my grandmother's garden.), so that by reading speakers would produce preferably prosodic structures congruent to these sentence syntactic structures. As speakers were all bilingual French/Basque and mostly trilingual (Basque/French/Spanish) we gave them the sentences in French and asked them to translate it into their native variety of Basque.

Our speakers were two females from Alava (Spain) and Labourd (France) and two males from Gipuzkoa (Spain). Recordings were made in a soundproof room with headset cardioid microphones. We then proceeded to a syllabic annotation of each sentence. Fundamental frequency curves were annotated with WinPitch's computer-assisted annotation function. To ensure better reliability in the annotation process, a spectrogram narrow band is simultaneously displayed with the fundamental frequency curve using exactly the same frequency scale.

\section{Results on stress' place}

The examination of syllables' duration and pitch showed that lexical words have their last syllable stressed. By last syllable we mean the very last, including the casual morpheme, and not just the last syllable of the word stem (as opposed to Michelena, 1997).

At the utterance level this examination also showed an expansion of duration and a progressive decrease of $\mathrm{F} 0$ on the three last syllables of the sentence when the said sentence was an assertion. Thus, when the verb is final, the first syllable of its stem is accented with an increase of duration and an increase of pitch, and its following syllables are lengthened and show a progressive decrease of pitch.

The final slope $\mathrm{C} 0$ starts on the last syllable of the verb's stem and spread itself to the last syllable of the verb's. For sentences where there is a continuation rise this rise happens on the two lasts syllable of the lexical word except if the word is disyllabic, in that case the rise is on the last syllable.

When there is a question mark the very last syllable of the sentence has a rising slope. For some sentences where speakers displayed evidence or doubt we also observed a hat slope on the last syllable of the sentence. For the 
sentences with focus, the focalization was realized as a hat slope on two syllables: a wide rise on the penultimate syllable and a falling slope on the last.

\section{A tentative prosodic grammar}

To go beyond phonetic observations, we attempted to sketch a limited prosodic grammar based on observations made on one single speaker native from Gipuzkoa (Spain).

The basic assumption is that the sentence prosodic structure organizes accent phrases in a hierarchy which is instanced by the melodic contours located on stressed syllables. Instead of ToBI tonal targets, we used the following melodic contours to annotate stressed syllables.

$\mathrm{C} 0$ terminal conclusive contour (assigned from perception of the prosodic end of the sentence).

Cc complex non-terminal contour, flat or slightly falling on the stressed vowel, and rising above the glissando threshold on the final syllable, combining both melodic movements if the final syllable is stressed.

$\mathrm{C} 1$ rising non-terminal contour, above the glissando threshold (Rossi, 1971).

$\mathrm{C} 2$ falling non-terminal contour, above the glissando threshold.

$\mathrm{Cn}$ neutralized rising, flat or falling contour, below the glissando threshold.

\section{Contrast of melodic slope, the case of assertions.}

For assertions, the $\mathrm{C} 0$ on the last syllable is instanced by a falling slope, a complex rising contour $(\mathrm{Cc})$ is displayed on the subject phrase, and the object phrase is displayed with a falling contour (C2).

\section{Contrast of melodic slope, the case of interrogative sentences.}

For interrogative sentences, we observed a pattern of contours in which the $\mathrm{C} 0$ (conclusive final) is rising, the subject has a falling contour $(\mathrm{C} 2)$ and the whole subject phrase has a complex rising contour $(\mathrm{Cc})$. When there is a subject and an object, the subject phrase has a falling contour (C2) and the object phrase is produced with a complex rising slope.

\section{Discussion}

Our results are consistent with Larramendi's findings, that claimed that the stress was located on the last syllable of words. Beyond stress position, the contours and prosodic patterns we evidenced addressed a new matter: we assume that $\mathrm{Cc}$ we observed on subject phrases could be grounded in the influence of Spanish intonation more than Basque prosodic patterns (which we also observed on two female speaker). As most Basque speaker are 
native bilingual or trilingual the influence of other languages is a tricky path to investigate.

We also observed that the hypothesis of assumed congruence between the prosodic and syntactic structures may not always be valid (especially when the sentence becomes more complex). Inside every object phrase we observed that contours were either $\mathrm{C} 2$ or $\mathrm{Cn}$ : for instance, in the phrase "katu zuri beltza" [tu] in "katu" is displayed with a C2 as well as [tza] in "beltza". We also noticed that kind of repetition in contours for subject phrases (where $\mathrm{C} 2$ are replaced by $\mathrm{C} 1$ ), however this did not appear on every subject phrase. In longer phrases, many contours were neutralized, giving form to plateau between the first and the last stressed syllable of the phrase.

\section{Acknowledgements}

We would like to thank Lorea, Maitane, Euken and Ibon for their time, patience, and their enthusiasm during the recordings, as well as the Pariseko Euskal Etxea.

\section{References}

Gavel, H. 1921. Eléments de phonétique basque. Sociedad de Estudios Vascos, Eusko Ikaskuntza

Goldsmith, J.A. 1976. Autosegmental phonology. Bloomington: Indiana University Linguistics Club, Vol. 159.

Larrasquet, J. 1928. Action de l'accent dans l'évolution des consonnes étudiée dans le Basque Souletin: étude expérimentale précédée de recherches expérimentales sur l'état actuel et l'évolution des vélaires dans le même dialecte.

Larramendi, M.D. 1729. El impossible vencido.

Hualde, J. I. 2004. Basque phonology. Routledge.

Martin, Ph. 1975. Analyse phonologique de la phrase française. Linguistics, 146, 35 68.

Martin, Ph. 2015. The Structure of Spoken Language. Intonation in Romance. Cambridge University Press.

Michelena, Luis. 1972. Etimología y transformación . Homenaje a Antonio Tovar, 305-317.

Michelena, Luis. 1977. La lengua vasca. Leopoldo Zugaza, Editor.

Michelena, L. 2013. A note on Old Labourdin accentuation. Anuario del Seminario de Filología Vasca" Julio de Urquijo", 6, 110-120.

Rossi, M. 1971. «Le seuil de glissando ou seuil de perception des variations tonales pour les sons de la parole. Phonetica, 23(1), 1-33.

WinPitch 2017. ww.winpitch.com. 